\title{
Characterization of two isolates of Trypanosoma cruzi obtained from the patient Berenice, the first human case of Chagas' disease described by Carlos Chagas in 1909
}

\author{
Received: 9 June 1995 / Accepted: 16 September 1995
}

\begin{abstract}
Two isolates of Trypanosoma cruzi were obtained from the patient Berenice, the first human case of Chagas' disease (Chagas 1909), when she was 55 and 71 years old, respectively. The isolates were characterized on the basis of their epimastigote-trypomastigote differentiation in liquid media and of the electrophoretic pattern of EcoR1 digestion products of kinetoplast DNA (kDNA) minicircles (schizodeme) and isoenzyme patterns (zymodeme). Clear differences were found between the isolates, suggesting the occurrence of a heterogeneous population of $T$. cruzi in the infection of this patient.
\end{abstract}

\section{Introduction}

Chagas' disease, an important health problem in Latin America, was discovered in Lassance, Minas Gerais state, Brazil, by Carlos Chagas (1909) when he examined the 2-year-old girl Berenice, describing the first human case of the disease. Afterward, two isolates of Trypanosoma cruzi were obtained from her through xenodiagnosis. The first isolate was obtained when she was 55 years old (Salgado et al. 1962) and the second, when she was 71 years old (Lana 1981). On both occasions, Bere-

\section{M. de Lana $(-)^{1}$ \\ Departamento de Análises Clínicas, Escola de Farmácia, \\ Universidade Federal de Ouro Preto, Rua Costa Sena,}

171, Centro, 35400, MG, Brasil

C.A. Chiari · E. Chiari

Departamento de Parasitologia, Instituto de Ciências Biológicas, C.P. 2486, Universidade Federal de Minas Gerais,

31270, Belo Horizonte, MG, Brasil

C.M. Morel - A.M. Gonçalves

Departamento de Bioquímica e Biologia Molecular, IOC-FIOCRUZ, Rio de janeiro, RJ, Brasil

\section{Á.J. Romanha}

Laboratório de Parasitologia Celular e Molecular, Centro de Pesquisas René Rachou, FIOCRUZ, Belo Horizonte, MG, Brasil

\section{Present address:}

${ }^{1}$ UMR CNRS/ORSTOM 9926:

"Génetique moléculaire des parasites e des vecteurs". ORSTOM. BP 5045. 34032 Montpellier Cédex 01, France Fax: (33) 67547800 nice was carefully examined and was considered normal in relation to all clinical forms of Chagas' disease (Salgado et al. 1962). She died at the age of 73 years, apparently due to causes other than Chagas' disease (Rocha 1992). Berenice exhibited a balanced human host- $T$. cruzi relationship and constitutes the best example of the indeterminate form of Chagas' disease (Garnham 1980).

The isolate obtained by Salgado et al. (1962) has been characterized and studied in many aspects by different authors (Brener 1965; Brener et al. 1974; Melo and Brener 1978) and has been further compared with the isolate obtained in 1978 (Lana 1981; Lana and Chiari 1986). In this study the production of trypomastigotes in liquid media and the zymodeme and schizodeme of both isolates were analyzed.

\section{Materials and methods}

Isolates of Trypanosoma cruzi

Two T. cruzi isolates were obtained via xenodiagnosis from the patient Berenice. The Be-62 isolate was obtained by Salgado et al. (1962) and isolate Be-78, by Lana (1981). Feces from infected triatomines used for xenodiagnosis were inoculated and maintained in mice. Furthermore, the isolates were reobtained from infected mice through hemoculture in liver infusion tryptose (LIT) medium. Be-62 was isolated in the 4th passage in albino mice. Be-78 was isolated in the 1st and 20th passages in $\mathrm{C} 3 \mathrm{H}$ mice, in the 1st and 40th passages in albino mice, and in the 6th cyclical passage in $\mathrm{C} 3 \mathrm{H}$ mice alternated with nymphs of the vector Dipetalogaster maximus.

\section{Differentiation in liquid media}

T. cruzi epimastigote-to-trypomastigote differentiation was evaluated when the samples were in the stationary phase of growth, between the 10th and 20th passages in culture. An inoculum of $2.5 \times 10^{7}$ parasites/ml was used in LIT (Camargo 1964) and M16 (Chiari and Camango 1984) media. These experiments were performed on 10-ml cultures in 50-ml Erlenmeyer flasks incubated at $28^{\circ} \mathrm{C}$. Differentiation was assessed every 2 days by differential counting of the flagellates in Giemsa smears. The results were expressed as the percentage of trypomastigotes found in 500 randomly counted flagellates. The experiments were carried out in triplicate and repeated at least twice. 
Isoenzyme analysis

The cultures were established in LIT media under stationary growth conditions at approximately 2 months after isolation from infected mice. Approximately $30 \mathrm{ml}$ of culture containing $5.0 \times 10^{7}$ flagellates $/ \mathrm{ml}$ was used. The flagellates were washed with phosphate-buffered saline (PBS) by centrifugation at $4^{\circ} \mathrm{C}$ and the pellet was stored at $-70^{\circ} \mathrm{C}$. The enzymatic extracts were obtained at $4{ }^{\circ} \mathrm{C}$ according to Kilgour and Godfrey (1973). The lysates were centrifuged at $15,000 \mathrm{~g}$ for $1 \mathrm{~h}$ at $4^{\circ} \mathrm{C}$. The supernatant, called the enzymatic extract, was cryopreserved in liquid nitrogen. Isoenzymes were separated by refrigerated horizontal thin-layer starch-gel electrophoresis. The enzymes studied were glucose-6-phosphate dehydrogenase (G6PD, EC.1.1.1.49), alanine aminotransferase (ALAT, EC.2.6.1.2), aspartate aminotransferase (ASAT, E.C.2.6.1.1), malic enzyme (ME, EC.1.1.1.40), phosphoglucomutase (PGM, EC.2.7.5.1), glucose phosphate isomerase (GPI, EC.5.3.1.9), malate desidrogenase (MDH, EC.1.1.1.37), and 6-phosphogluconate desidrogenase (6PGD, EC.1.1.1.44). As references, T. cruzi strains from zymodemes A, B, C, and D were used (Carneiro et al. 1990).

\section{Schizodeme analysis}

The pellet of parasites obtained previously was used for extraction and purification of kinetoplast DNA (k-DNA; Gonçalves et al. 1984). K-DNA was digested with EcoR 1 for $1.5 \mathrm{~h}$ at $37^{\circ} \mathrm{C}$. KDNA fragments were separated by vertical electrophoresis in $6-10 \%$ polyacrylamide gradient slab gels. The fluorescence patterns were visualized and photographed after staining with ethidium bromide and transillumination with UV light.

\section{Results}

Differentiation in liquid media

Be-62 showed a lower percentage of epimastigote-to-trypomastigote differentiation than did Be-78 (Fig. 1). Both isolates presented higher differentiation rates in M16

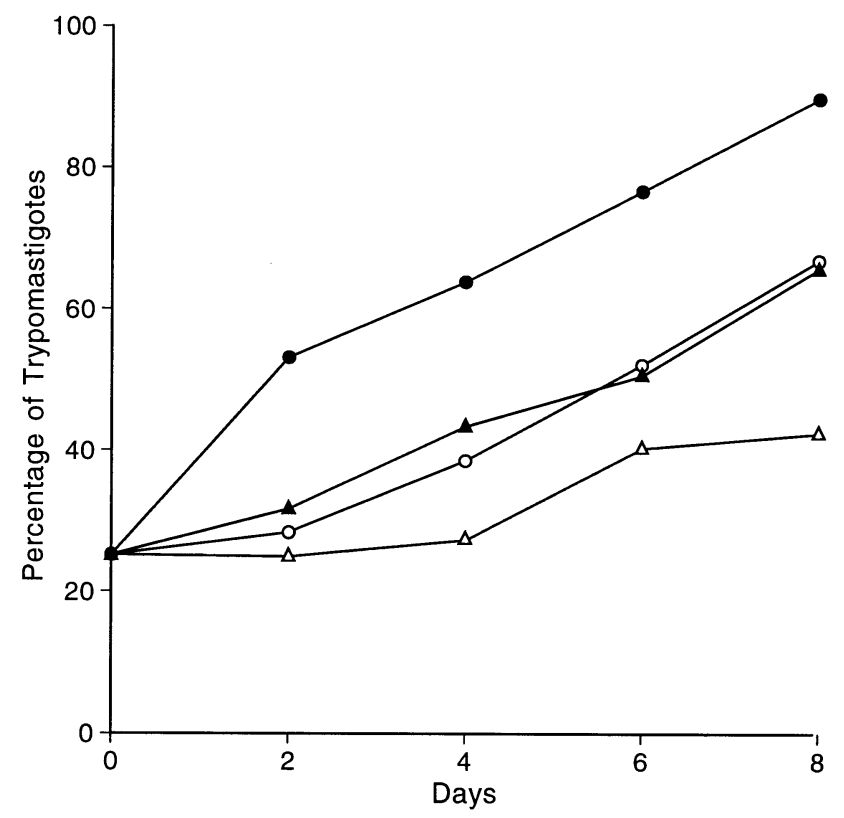

Fig. 1 Epimastigote-to-trypomastigote differentiation in LIT and M16 media of Be-62 and Be-78 isolates of Trypanosoma cruzi. Symbols: $\longrightarrow$ M16-Be-78; $\bigcirc$ LIT-Be-78; $\longrightarrow$ M16-Be-62; $\hookrightarrow$ LIT-Be-62 medium than in LIT medium. Nevertheless, Be-62 showed the same differentiation profile in M16 medium as did Be-78 in LIT medium. Similar results were also obtained when parasites were harvested from infected mice at different numbers of blood passages (data not shown).

\section{Isoenzyme patterns}

Be-62 showed typical patterns of zymodeme A for all enzymes tested. Be-78 displayed typical patterns of zymodeme A in six of the eight enzymes tested. However, PGM and MDH showed a pattern typical of zymodeme B (Fig. 2). The conditions of maintenance and the number of successive blood passages did not change the isoenzyme profiles.

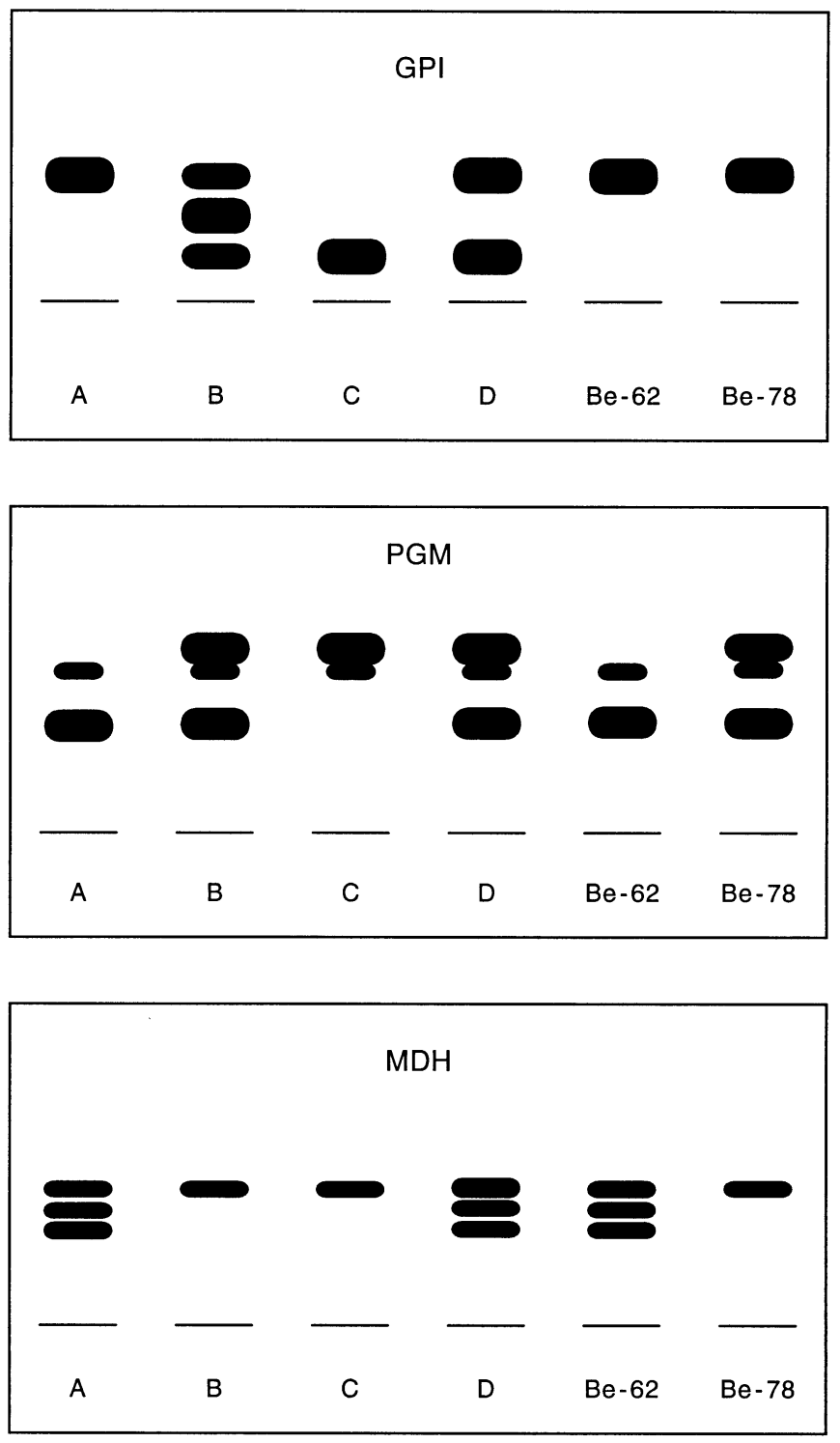

Fig. 2 Diagram of the isoenzyme patterns of the discriminatory enzymes GPI, PGM, and MDH of Be-62 and Be-78 T. cruzi obtained from infected mice (A,B,C, D Standard zymodemes) 


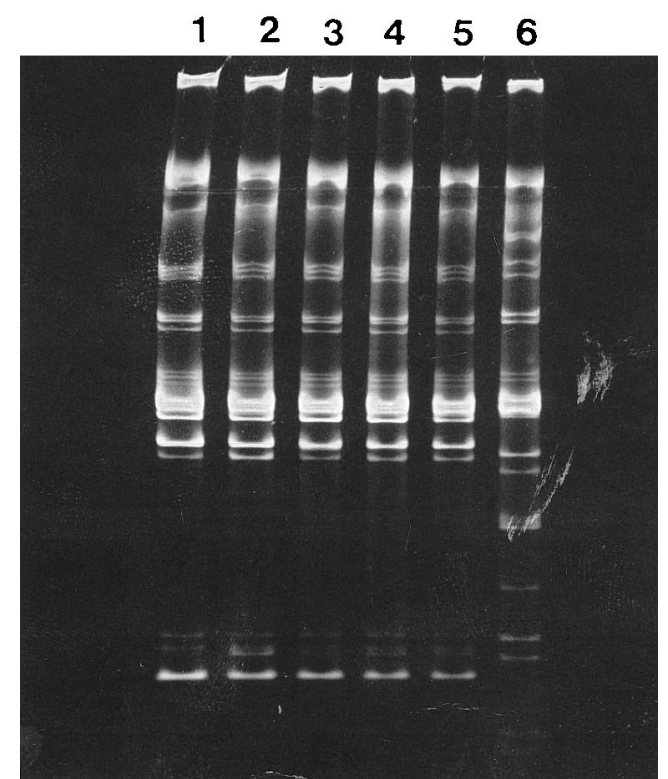

Fig. 3 Schizodeme patterns of Be-62 and Be-78 T. cruzi isolates obtained from infected mice at different passages. The k-DNA was previously digested by EcoR 1 restriction enzyme. Be-78 isolate: (1) 1st passage in $\mathrm{C} 3 \mathrm{H}$ mice, (2) 20th passage in $\mathrm{C} 3 \mathrm{H}$ mice, (3) 1 st passage in albino mice, (4) 40th passage in albino mice, (5) 6th cyclical passage in Dipetalogaster maximus-C3H mice. Be-62 isolate: (6) 4th passage in albino mice

\section{K-DNA patterns}

Isolates Be-62 and Be-78 displayed different restriction endonuclease profiles (k-DNA) when cleaved with EcoR1. They could be differentiated by alterations in low-molecular-weight fragments. The conditions of maintenance and the number of successive blood passages in mice did not change the k-DNA patterns of the two isolates studied (Fig. 3).

\section{Discussion}

The epimastigote-to-trypomastigote differentiation in culture of Be-62 and Be-78 isolates was the same when the parasites were harvested from mice at different passages. The differentiation was always higher in M16 medium than in LIT medium. Neither the type of maintenance nor the number of passages of either isolate in mice changed the zymodeme, the schizodeme, or the rate of differentiation, making these parameters suitable for characterizing both Trypanosoma cruzi isolates (Camargo 1964; Romanha 1982; Chiari and Camargo 1984; Gonçalves et al. 1984).

Although isoenzyme analysis of the Be-62 T. cruzi isolate was not performed on its acquisition from the patient in 1962, many years later, after successive blood passages in mice, this strain showed isoenzyme patterns typical of zymodeme A in all eight enzymes tested. On the other hand, the Be-78 isolate, analyzed immediately after isolation, showed zymodeme A patterns in six of the eight enzymes, the exceptions being PGM and MDH. With these enzymes, Be-78 showed profiles from zymodeme B. Our data suggest the occurrence of a heterogeneous population of $T$. cruzi in the infection of the patient Berenice. Similar results were observed by Romanha (1982) in some chronic chagasic patients of Bambui city, Minas Gerais state, Brazil. It cannot be excluded that Berenice may have acquired a second infection with a certain strain of $T$. cruzi. It also cannot be excluded that during the life of Berenice, some $T$. cruzi parasites may have been eliminated step by step by her immune system such that the Berenice strains isolated from the same patient at different times show different biochemical characteristics.

Many authors have described the isolation of heterogeneous $T$. cruzi populations from the same patient as well as other vertebrate and invertebrate hosts. Morel et al. (1980) have demonstrated that the standard CL "strain", isolated from a Triatoma infestans, is actually a mixture of at least two subpopulations that differ in their biological and biochemical properties. Marques de Araujo and Chiari (1988) cloned this strain and encountered biological and biochemical differences among the subpopulations. Brenière et al. $(1985,1989)$ showed that $13.0 \%$ and $12.3 \%$, respectively, of chagasic Bolivian patients were infected with at least two different T. cruzi zymodemes. These results were observed after the parasites had been obtained either through the same triatomine or via different triatomine specimens used for the same xenodiagnosis. There is also experimental evidence of the coexistence of more than one strain of T. cruzi in the same host. Deane et al. (1984) demonstrated this finding in mice inoculated with the $\mathrm{Y}$ and $\mathrm{F} T$. cruzi strains through schizodeme and zymodeme analysis. Alves et al. (1993) described reversible changes in the isoenzyme patterns and infectivity to mice of clones obtained from the standard $T$. cruzi $\mathrm{Y}$ strain after its maintenance under different conditions in the laboratory.

It has been shown that zymodeme A is very common in chronic patients in many regions of Brazil (Romanha 1982; Schlemper 1982). This zymodeme is equivalent to the zymodeme $\mathrm{Z} 2$ from the domestic cycle (Miles et al. 1981; Luquetti et al. 1986) reported in different regions of Brazil.

The two isolates Be-62 and Be-78 were also different when the k-DNA profile was analyzed using EcoRI. This parameter confirms and extends the characterization by isoenzyme analysis (Carneiro et al. 1990). Neither the type of maintenance nor the number of successive passages in mice changed the zymodeme or the schizodeme of either isolate.

Taken as a whole, these results address some intriguing questions concerning the $T$. cruzi-human interaction:

1. Was the patient Berenice infected once or at different times by more than one clone or population of $T$. cruzi?

2. Did the process of isolation (xenodiagnosis) select different $T$. cruzi populations on each occasion? 
3. Can a different population of $T$. cruzi be selected by the patient's immune system during the chronic phase of the infection?

At present, both isolates are being cloned and studied to clarify some of these questions.

Acknowledgements This work received financial support from the CNPq and UNDP/World Bank/WHO Special Program for Research and Training in Tropical Diseases, TDR.

\section{References}

Alves AMB, Tanuri A, De Almeida DF, Krüger WMA von (1993) Reversible changes in the electrophoretic mobility pattern and infectivity in clones of Trypanosoma cruzi. Exp Parasitol 77: 246-253

Brener Z (1965) Comparative studies of different strains of Trypanosoma cruzi. Ann Trop Med Parasitol 59: 19-26

Brener Z, Chiari E, Alvarenga NJ (1974) Observations on Try panosoma cruzi strains maintained over 8 years in experimentally inoculated mice. Rev Inst Med Trop Sao Paulo 16: 3946

Brenière SF, Tibayrenc M, Antezana G, Pabon J, Carrasco R, Selaès H, Desjeux P (1985) Preliminary results in favor of a weak or non-existent relationship between the clinical forms of Chagas' disease and Trypanosoma cruzi isozymic strains. C R Acad Sci [III] 300: 555-558

Brenière SF, Carrasco R, Revollo S, Aparicio G, Dejeux P, Tibayrenc M (1989) Chagas' disease in Bolivia: clinical and epidemiological features and zymodeme variability of Trypanosoma cruzi isolated from patients. Am J Trop Med Hyg 41: 521529

Camargo EP (1964) Growth and differentiation in Trypanosoma cruzi. I. Origin of metacyclic trypanosomes in liquid media. Rev Inst Med Trop Sao Paulo 6: 93-100

Carneiro M, Chiari E, Gonçalves AM, Silva Pereira AA, Morel CM, Romanha AJ (1990) Changes in the isoenzyme and kinetoplast DNA patterns of Trypanosoma cruzi strains induced by maintenance in mice. Acta Trop (Basel) 47: 35-45

Chagas C (1909) Nova tripanosomiase humana: estudos sobre a morfologia e o ciclo evolutivo do Schisotrypanum cruzi $\mathrm{n}$. gen., n. sp., agente etiolójico de nova entidade morbida do homem. Mem Inst Oswaldo Cruz 1: 159-218

Chiari E, Camargo EP (1984) Culturing and cloning of Trypanosoma cruzi. In: Morel CM (ed) Genes and antigens of parasites. A laboratory manual. Fundação Oswaldo Cruz, Rio de Janeiro, pp 23-26
Deane MP, Sousa MA, Pereira NM, Gonçalves AM, Momen H, Morel CM (1984) Trypanosoma cruzi: inoculation schedules and reisolation methods. Select individual strains from doubly infected mice, as demonstrated by schyzodeme and zymodeme analysis. J Protozool 31: 276-280

Garnham PCC (1980) The significance of inapparent infections in Chagas' disease and other forms of trypanosomiasis. Mem Inst Oswaldo Cruz 75: 181-188

Gonçalves AM, Neheme NS, Morel CM (1984) Trypanosomatid characterization by schizodeme analysis. In: Morel CM (ed) Genes and antigens of parasites. A laboratory manual Fundação Oswaldo Cruz, Rio de Janeiro, pp 95-109

Kilgour V, Godfrey DG (1973) Species-characteristic isoenzymes of two aminotransferases. Nat New Biol 244: 69-70

Lana M (1981) Caracterização do Trypanosoma cruzi, cepas Berenice, isoladas da mesma paciente em diferentes períodos. Master's thesis, UFMG, Belo Horizonte, MG

Lana M, Chiari CA (1986) Caracterização biológica comparativa das cepas Berenice-62 e Berenice-78 de Trypanosoma cruzi isoladas da mesma paciente em diferentes períodos. Mem Inst Oswaldo Cruz 81: 247-253

Luquetti AO, Miles MA, Rassi A, Resende JM, Souza AA, Povoa MM, Rodrigues I (1986) Trypanosoma cruzi: zymodemes associated with acute and chronic Chagas' disease in central Brazil. Trans R Soc Trop Med Hyg 80: 462-480

Marques de Araujo S, Chiari E (1988) Caracterizaçao biologica de clones das cepas Y, CL e MR de Trypanosoma cruzi em camundongos $\mathrm{C} 3 \mathrm{H}$ isogênicos. Mem Inst Oswaldo Cruz 83: 175-181

Melo RC, Brener Z (1978) Tissue tropism of different Trypanosoma cruzi strains. J Parasitol 64: 475-482

Miles MA, Povoa MM, Prata A, Cedillos RA, Souza AA, Macedo V (1981) Do radically dissimilar Trypanosoma cruzi strains (zymodemes) cause Venezuelan and Brazilian forms of Chagas' disease"? Lancet II: 1338-1340

Morel C, Chiari E, Camargo EP, Mattei DM, Romanha AJ, Simpson L (1980) Strains and clones of Trypanosoma cruzi can be characterized by pattern of restriction endonuclease products of kinetoplast DNA minicircles. Proc Natl Acad Sci USA 77: $6810-6814$

Rocha LOS (1992) Vida e obra de Luigi Bogliolo. Gráfica da Fundação Cultural, Belo Horizonte, MG, pp 356-357

Romanha AJ (1982) Heterogeneidade enzimática em Trypanosoma cruzi. PhD thesis, UFMG, Belo Horizonte, MG

Salgado JA, Garcez PN, Oliveira CA (1962) Revisão clínica atual do primeiro caso humano descrito da doença de Chagas. Rev Inst Med Trop São Paulo 4: 330-337

Schlemper BR Jr (1982) Caracterização de cepas do Trypanosoma cruzi isoladas de pacientes com diferentes formas clínicas da doença de Chagas. Master's thesis, UFMG, Belo Horizonte, MG 